K A N D A I

\begin{tabular}{|l|l|l|}
\hline Volume 14 & No. 2, November 2018 & Halaman 149-168 \\
\hline
\end{tabular}

\title{
PENGETAHUAN PERATURAN KEBAHASAAAN \\ DALAM MEMENGARUHI SIKAP BAHASA PEDAGANG MAKANAN \\ DI KOTA METRO
}

(The Influence of Language Regulation Knowledge to the Language Attitude of Culinary Entrepreneur at Kota Metro)

\author{
Achril Zalmansyah, Kiki Zakiah Nur, \& Mukhammad Isnaini \\ Kantor Bahasa Provinsi Lampung \\ Jalan Beringin II Nomor 40 Kompleks Gubernuran, Telukbetung, \\ Bandarlampung, Indonesia \\ Pos-el: zzalmansa@gmail.com
}

(Diterima: 2 Februari 2018; Direvisi: 4 Mei 2018; Disetujui: 4 Mei 2018)

\begin{abstract}
This study discusses how the knowledge of language regulations influences on culinary entrepreneur attitude in Kota Metro, Lampung Province. The research's objectives are to reveal (1) how is the knowledge of culinary entrepreneur in Kota Metro towards the language regulations, (2) the culinary entrepreneurs' attitude towards the use of bahasa Indonesia and foreign language, (3) the influence of knowledge about language regulation on culinary entrepreneur attitude in Kota Metro. The method used is survey method with the aim of describing and interpreting things related to today's conditios or symptoms. The result of analysis indicates that the culinary entrepreneur's knowledge of language regulation of the culinary entrepreneurs in Kota Metro is very low. However, the attitude of the language of culinary entrepreneurs in Kota Metro is very good. The knowledge of culinary entrepreneurs in Kota Metro about the laws and regulations related to the language and the use of Indonesian and foreign languages has very little effect on their language attitude.
\end{abstract}

Keywords: language rules, language attitude, culinary entrepreneur

\begin{abstract}
Abstrak
Penelitian ini membahas tentang bagaimana pengetahuan kebahasaan para pedagang makananyang ada di kota Metro berpengaruh terhadap sikap bahasa mereka. Tujuannya adalah untuk mengetahui (1) bagaimana pengetahuan para pedagang makanan Kota Metro terhadap peraturan perundang-undangan tentang kebahasaan, (2) sikap para pedagang makanan Kota Metro tentang penggunaan bahasa Indonesia dan asing, serta(3) pengaruh pengetahuan peraturan kebahasaan terhadap sikap bahasa para pedagang makanan Kota Metro. Metode yang dipakai adalah metode survei dengan tujuan mendeskripsikan dan menafsirkan hal yang berkenaan keadaan atau kondisi saat ini. Hasil analisis menunjukkan bahwa pengetahuan tentang peraturan kebahasaan para pengusaha kuliner Kota Metro sangat rendah. Akan tetapi, sikap bahasa pengusaha kuliner di Kota Metro sangat baik. Adapun pengetahuan pengusaha kuliner di Kota Metro mengenai peraturan perundang-undangan yang berkaitan dengan bahasa dan penggunaan bahasa Indonesia dan asing sangat tidak memengaruhi sikap bahasa mereka.
\end{abstract}

Kata-kata kunci: peraturan kebahasaan, sikap bahasa, pedagang makanan 
DOI: $10.26499 / j k . v 14 i 2.564$

How to cite: Zalmansyah, A., Zakiah Kiki, N. \& Isnaini, M. (2018). Pengetahuan peraturan kebahasaan dalam memengaruhi sikap bahasa pedagang makanan di kota metro. Kandai, 14(2), 149-168 (DOI: 10.26499/jk.v14i2.564)

PENDAHULUAN

Bahasa sebagai alat komunikasi merupakan bagian yang tidak terpisahkan dari manusia. Dari bahasa, seseorang dapat mengerti dan mengetahui keinginan sipembicara. Dari bahasa, kita dapat mengenal adat istiadat, budaya, bahkan asal seseorang. Manusia dapat berinteraksi, berkomunikasi, dan mengembangkan dirinya dengan bahasa (Pamungkas dalam Putri, 2018). Selanjutnya dapat dikatakan bahwa bahasa merupakan identitas diri daerah dan bangsa (Samsuri, 1986).

Saat ini komunikasi tidak hanya terjadi secara lisan saja. Seiring dengan perkembangan zaman yang juga diiringi dengan perkembangan teknologi, proses komunikasi juga menjadi lebih berkembang melalui tulisan. Komunikasi dapat dilakukan pula dengan tanpa bertatap muka yaitu dengan memanfaatkan teknologi (A'ini, et.al, 2018).

Ragam bahasa tulis, sebagai contohnya bahasa yang ada di ruang publik sangat mudah dijumpai dan banyak yang menggunakan bahasa Inggris atau asing. Tidak hanya di papan nama, tetapi juga di papan petunjuk dan ini terjadi hampir di seluruh wilayah tanah air. Ambil saja contoh yang ada di lingkungan kita saja, seperti nama gerai Bambu Kuning Square, Grand Anugrah Hotel, Tiara Food Station, Café Dawiel, perumahan Citra Garden, Springhill Condotel, dan sebagainya. Belum lagi penggunaan kata asing seperti in dan out, bukan kata keluar dan masuk, penggunaan istilah meeting room daripada ruang pertemuan, welcome daripada selamat datang, dan kata men- women daripada pria-wanita. Penggunaan istilah asing pada hampir semua bidang kehidupan memang tidak terelakkan. Penyebabnya antara lain: hal atau sesuatu yang baru yang bersala dari luar, belum adanya padanan kata terhadap hal atau benda tersebut di dalam bahasa Indonesia, dan sikap masyarakat pengguna bahasa yang probahasa asing ketimbang bahasa lokal. Hal ini berakibat pada terdesaknya istilah lokal yang memang sudah ada dan keengganan untuk menggunakannya. Fakta tersebut menunjukkan kecenderungan bahasa asing yang memiliki tren menggeser penggunaaan bahasa Indonesia. Kecenderungan ini dapat kita amati pada berbagai reklame, baliho, papan nama, spanduk, nama hotel, rumah makan, atau nama instansi, nama perusahaan, dan sebagainya. Hal ini tentu berkaitan dengan sikap bahasa masyarakat pengguna bahasa. Sikap bahasa paling sedikit mengandung tiga ciri pokok, loyalitas bahasa, bangga berbahasa, dan sadar akan norma bahasa (Garvin \& Mathiot dalam Suwito, 1983) mengemukakan bahwa. Oleh karena itu, ketika seseorang menggunakan suatu bahasa, tentu ia akan memiliki sikap di dalam berbahasa, baik positif maupuin negatif. Ditambahkan Fishman (1964) bahwa berbagai kemungkinan hubungan antara sikap di dalam penggunaan bahasa juga tidak dapat dimungkiri. Meskipun demikian, Lambert mungkin melaporkan adanya hubungan positif antara keberhasilan siswa sekolah dasar dalam pembelajaran bahasa kedua dan sikap yang baik terhadap bahasa kedua dan penuturnya.

Sikap bahasa adalah salah satu objek penelitian yang menarik untuk diteliti. Penelitian yang berhubungan 
dengan sikap bahasa pernah dilakukan di Lampung (Isneni, et.al, 2005) tentang sikap bahasa masyarakat terhadap bahasa Lampung. Penelitian tersebut membuktikan sikap positif masyarakat terhadap bahasa Lampung. Hal ini membuktikan adanya pewarisan bahasa antargenerasi. Pewarisan ini terlihat dari sebagian besar responden yang menyatakan bahwa bahasa Lampung masih digunakan para orang tua ketika berbicara dengan anaknya, begitu pun sebaliknya.

Penelitian tentang sikap orang Irlandia terhadap bahasa mereka pernah dilakukan oleh Brudner dan White dengan bukti bahwa orang Irlandia lebih menyukai pengunaan bahasa Inggris ketimbang bahasa mereka Selain itu, Samarin dan Kalmar meneliti sikap bahasa para imigran Kanada terhadap bahasa Inggris orang pendatang. Mereka merekam wacana pendek berbahasa Inggris dari orang Italia yang telah lulus seleksi. Hasil penelitian menunjukkan bahwa makin baik seseorang dalam berbahasa Inggris makin mudah mereka memperoleh pekerjaan (Sugiyono \& Sasangka, 2011)

Berkaitan dengan sikap bahasa, penelitian ini mengambil objek sikap bahasa para pedagang makanan. Mereka menggunakan papan nama toko atau kedainya sebagai media promosi yang dipajang di pinggir jalan dan mudah dilihat sekilas jika melintas di jalan tersebut. Kota Metro menjadi sasaran tempat pengambilan data karena kota ini memiliki banyak pedagang makanan atau usaha kuliner yang berjualan di sepanjang jalan di kota Metro.

Tujuan penelitian ini untuk mengetahui (1) pengetahuan pedagang makanan di Kota Metro mengenai peraturan perundang-undangan yang berkaitan dengan bahasa dan penggunaan bahasa Indonesia dan asing, (2) sikap pedagang makanan di Kota
Metro terhadap bahasa dan penggunaan bahasa Indonesia dan asing, serta (3) pengaruh pengetahuan mengenai peraturan kebahasaan terhadap sikap bahasa pengusaha kuliner di Kota Metro.

Hasil penelitian ini diharapkan dapat bermanfaat untuk pengembangan linguistik, khususnya sosiolingusitik. Diperolehnya simpulan mengenai pengetahuan tentang kebahasaan pedagang makanan dan pengaruhnya terhadap sikap bahasa para pedagang makanan di Kota Metro akan menjadi data mengenai sikap bahasa mereka dan dapat menjadi acuan untuk penelitian sejenis dengan ranah lain atau dasar bagi penelitian mengenai penggunaan bahasa asing yang banyak dipakai para pedagang makanan tersebut, terutama di kota besar. Selain itu, hasil penelitian ini dapat digunakan untuk menentukan regulasi dan kebijakan, penggunaan bahasa di ruang publik di Provinsi Lampung.

\section{LANDASAN TEORI}

Teori tentang sikap bahasa dalam kaitannya dengan kajian sosiolinguistik memandang bahasa sebagai suatu institusi sosial, baik indivisu mauopuin kelompok masyarakat di dalam interaksi sosialnya. Menurut Fishman (dalam Chaer \& Agustina, 2010, hlm. 3), sosiolinguistik adalah kajian tentang ciri khas variasi bahasa, fungsi-fungsi variasi bahasa, dan pemakai bahasa karena ketiga unsur itu selalu melakukan interaksi dan perubahan serta saling mengubah satu sama lain dalam satu masyarakat tutur.

Selanjutnya, Chaer dan Agustina (2010) menambahkan bahwa bahasa sebagai bagian dari sosiolinguistik sebagai perpaduan antara ilmu sosiologi dan linguistik. Sosiologi di dalam hal ini merupakan suatu kajian ilmiah tentang manusia dan mengenai lembaga- 
lembaga, serta proses sosial yang ada di dalamnya. Cara-cara menyesuaikan diri dengan lingkungannya dapat diketahui dengan mempelajari masalah-masalah sosial dan lembaga sosial yang ada di suatu masyarakat. Sedangkan ilmu yang mempelajari tentang bahasa dikenal sebagai ilmu linguistik. Dengan demikian, sosiolinguistik dapat dikatakan sebagai bidang ilmu antardisplin yang mempelajari bahasa dan bagaimana penggunaan bahasa itu di dalam masyarakat.

Sosiolinguistik merupakan ilmu yang dianggap baru dan menuntut agar kehadirannya sejajar dengan ilmu-ilmu lain. Sosiolinguistik menuntut keikutsertaannya di dalam pengambilan kebijakan yang berkaitan dengan kebahasaan. Hal ini disebabkan kajian sosiolinguistik menghubungkan antara bahasa dengan hal-hal yang bersifat sosio-kultural. Sikap bahasa (language attitude) seseorang pengguna bahasa bisa positif maupun negatif. Sedangkan bahasa merupakan sistem lambang bunyi yang arbiter yang digunakan oleh anggota suatu masyarakat untuk berinteraksi dan mengidentifikasikan diri (Badan Bahasa, Depdiknas, 2014).

Sikap bahasa sebagai sebuah istilah adalah perilaku, gerak-gerik dan perbuatan berlandaskan pendirian, pandangan, pendapat, dan keyakinan. Bahasa, baik bahasa nasional, bahasa daerah, mapupun bahasa asing adalah alat komunikasi yang digunakan oleh penutur atau pemakai bahasa untuk mengutarakan kehendak, maksud, atau harapan agar dapat bekerja sama, berinteraksi, dan mengidentifikasikan diri (Chaer \& Agustina, 2010, hlm. 149).

Menurut Ridwan (2006, hlm. 211), sikap bahasa merupakan suatun psosisi mental atau perasaan terhadap bahasa sendiri atau bahasa orang lain. Sementara itu, Anderson mendefinisikan (dalam Chaer \& Agustina, 2010) sikap bahasa sebagai tata keyakinan yang berhubungan dengan bahasa dan berlangsung relatif lama, tentang suatu objek bahasa dan cenderung bertindak dengan cara tertentui yang disukainya. Pendapat Cooper and Fishman (dalam Lucas, 2004, hlm 184) adalah bahwa secara umum, ada keterkaitan antara perasaan atau sikap dan bahasa, pengetahuan atau kemampuan berbicaranya.

Yuliadi (2013) dalam penelitiannya juga menyinggung tentang sikap bahasa. Bagaimana keyakinan penutur terhadap suatu bahasa dapat mecerminkan sikap; bagaimana perasaan penutur terhadap bahasa itu; serta bagaimana ia bertindak tutur terhadap suatu bahasa.

Lambert (dalam Chaer, 2004) mengatakan bahwa sikap terdiri atas unsur kognitif, afektif, dan psikomotorik. Kognitif berkaitan dengan masalah pengetahuan akan alam sekitar dan gagasan yang kategorinya digunakan dalam proses berpikir. Afektif berkaitan dengan masalah penilaian, suka atau tidak suka terhadap suatu situasi. Apabila dia suka, merasa senang atau mempunyai rasa baik pada suatu situasi, orang tersebut dapat dikatakan mempunyai sikap positif, namun sebaliknya jika dia mempunyai rasa tidak baik atau senang pada suatu situasi, ia mempunyai sikap negatif. Psikomotorik berhubungan dengan perilaku atau perbuatan seseorang dalam mengambil keputiusan terakhir terhadap suatu keadaan. Ditambahlan oleh Lucas (2004) bahwa sikap bahasa penutur, baik negatif maupun positif dapat menentukan tingkat pengetahuannya terhadap bahasa itu, sebagaimana penggunaannya sehari-hari.

Sikap bahasa menurut Garvin dan Mathiot (dalam Halim, 1983) mengandung tiga ciri pokok, dalam poin-poin berikut ini. 
1. Sikap kesetiaan suatu masyarakat pengguna bahasa mempertahankan bahasanya jika ada pengaruh asing.

2. Sikap bangga berbahasa yang mendorong seseorang mengembangkan bahasanya dan menggunakannya sebagai lambang identitas dan kesatuan masyarakatnya.

3. Sikap sadar akan norma bahasa sehingga dapat menggunakan bahasanya dengan cermat dan santun sebagai faktor yang berpengaruh terhadap kegiatan pengunaan bahasanya.

Ciri-ciri sebagaiman dijabarkan di atas, merupakan ciri positif pengguna bahasa. Apabila ketiga ciri tersebut melemah, hal ini menunjukkan sikap negatif seorang pengguna bahasa terhadap bahasanya. Lebih lanjut diungkapkannya bahwa pendekatan psikologi sosial sebagai salah satu alternatif pendekatan terhadap sikap bahasa yang berkasitan dengan perilaku manusia dalam hubungan sosialnya, yang berdampak terhadap sikap positif maupun negatif terhadap suatu bahasa.

Penutur atau pemakai bahasa dapat mengevaluasi suatu bahasa yang mempunyai ciri berikut: kaya, miskin, indah, jelas, lemah, lembut, dan sebagainya berlandaskan pendapat dan rasa bahasanya. Sikap merupakan gejala mental yang menggambarkan keadaan individual (Fasold dalam Ridwan, 2006, hlm 215). Berdasarkan pandangan di atas, terdapat kaidah sikap bahasa, yaitu sebagai berikut.

1. Sikap yakin sebagai motivasi dalam peningkatan dan pembinaan kemampuan berbahasa.
2. Sikap liberal sebagai sikap yang akan keterbukaan tanpa batas. Sikap ini berisiko membahayakan akan bahasa sendiri dan terlalu mengagungkan bahasa lain.

3. Sikap positif akan kaidah atau aturan kebahasaan yang mengarak kepada kearifan dan kecendekiaan berbahasa.

4. Sikap acuh tak acuh dalam berbahasa dengan tidak memperhitungkan akibat psikologis atau sosial (Ridwan, 2006, hlm. 215).

Selanjutnya, empat fungsi sikap bagi individu: (1) sikap positif atau negatif individu. Sikap positif adalah membantu atau menguntungkan individu, sedangkan sikap negatif adalah sikap tidak suka terhadap objek yang menghalangi atau menghukum individu; (2) sikap yang berfungsi sebagai pengetahuan sikap merupakan pengetahuan individu terhadap lingkungan; (3) sikap yang berfungsi mengungkapkan nilai dasar di dalam upaya peningkatan citra diri atau individu; dan (4) sikap yang berfungsi melindungi individu dari pikiran atau perasaan yang mengancam citra diri.

Mengingat adanya kecenderungan menggunakan bahasa asing, terutama dalam penamaan kuliner atau hal yang berkaitan dengan makanan, penelitian ini berfokus pada pengaruh pengetahuan tentang peraturan kebahasaan terhadap sikap pengusaha kuliner. Lokus penelitian ini adalah salah satu kota yang ada di Provinsi Lampung, yaitu Kota Metro dengan asumsi bahwa di kota ini banyak terdapat usaha kuliner atau pedagang makanan. 


\section{METODE PENELITIAN}

Metode deskriptif dan pendekatan sosiolinguistik digunakan pada penelitian ini dengan pertimbangan bahwa sosiolinguistik termasuk teori atau ilmu yang berkaitan dengan pemakaian bahasa dalam kaitannya dengan masyrakat (Chaer \& Agustina, 2010). Selanjutnya, peneliti mengunakan pendekatan kuantitatif yang bersifat deskriptif, yaitu menafsirkan data yang didapat dari kuesioner yang berkaitan dengan fakta, variabel, dan fenomena ada pada saat penelitian dengan apa adanya.

Pengambilan sampel dari populasi dilakukan dengan metode survei, selanjutnya data yang telah dikumpulkan melalui penyebaran angket atau kuesioner sebagai alat pengumpul data yang utama. Wiseman dan Aron (dalam Mahsun, 2005) menyatakan bahwa metode survei adalah penyediaan data yang dilakukan dengan penyebaran kuesioner atau daftar tanyaan yang terstruktur dan rinci untuk memperoleh informasi dari sejumlah besar informan yang dipandang representatif mewakili populasi penelitian. Penerapan metode ini dilakukan guna mendeskripsikan dan menafsirkan hal yang berkaitan dengan suatu gejala atau kondisi apa adanya, sebagai gejala faktual dan kaitannya dengan berbagai variabel masalah secara sistematis.

Penelitian ini menggunakan populasi kelompok subjek yang harus memiliki ciri-ciri atau karakteristik bersama yang membedakannya dengan kelompok subjek lain. Fokusnya pada pedagang makanan atau kuliner yang ada di Kota Metro. Penelitian sosiolinguistik yang hasilnya telah diterbitkan ternyata menggunakan sampel dalam jumlah yang tidak besat (Ahsen dalam Mahsun, 2005). Oleh karena itu, penelitian di Kota Metro ini menggunakan sampel dengan jumlah 100 orang dari populasi pedagang makanan yang ada di kota ini.

Sikap bahasa merupakan variabel utama penelitian ini. Sementara variabel pendukung di antaranya jenis kelamin, usia, status perkawinan, pendidikan, bahasa pertama, dan bahasa lain yang dikuasai selain bahasa pertama. Pemerolehan data melalui pengamatan di lapangan mengenai papan nama dan kain rentang di Kota Metro yang berkaitan dengan kuliner dan sebaran angket untuk mengetahui sikap bahasa mayarakat pedagang makanan atau kuliner. Selanjutnya, data yang diperoleh sebagai data kuantitatif (berupa angka-angka) dari hasil pengukuran atau daftar tanyaan berkaitan dengan pengetahuan perundang-undangan dan pernyataan tentang sikap. Data yang terkumpul diolah dengan langkah awal membuat tabulasi skor angket sikap bahasa dan pengetahuan bahasa para pedagang makanan, dilanjutkan dengan membuat skor keseluruhan sebagai hasil tes sebagai tahapan selanjutnya.

\section{Indikator Sikap Bahasa, Klasifikasi dan Perhitungan Indeks}

Seseorang dianggap bersifat positif terhadap sebuah bahasa apabila orang itu mempunyai kemampuan yang baik terhadap bahasa itu, mempunyai impresi yang baik, masih menggunakan bahasa itu dalam berbagai ranah, dan mampu menurunkan penggunaan bahasa itu kepada generasi di bawahnya (Sugiyono \& Sasangka, 2011).

Angket yang didistribusikan terdiri atas: (1) profil responden dengan 7 pertanyaan tertutup yang dilanjutkan dengan (2) pengetahuan tentang peraturan kebahasaan yang terdiri atas 5 pertanyaan. Responden diharapkan menjawab pertanyaan dengan jawaban $y a$ atau tidak. Jika menjawab $y a$, jawaban dikonversi ke dalam 4 nilai 
dengan bobot (2, 3, 4, dan 5). Jawaban yang benar dan lengkap diberi bobot 5; jawaban yang benar, tetapi kurang lengkap diberi nilai 4; nilai 3 diberikan untuk jawaban ya; tetapi jawaban yang diberikan tidak tepat; dan nilai 2 diberikan kepada responden yang menjawab ya, tetapi tidak memberikan komentar mengenai isi perundangundangan (jawaban untuk isi perundang- undangan kosong). Responden yang menjawab tidak diberi nilai 1 .

Bagian ketiga angket adalah pernyataan yang terkait dengan sikap bahasa. Ada 36 pernyataan yang merupakan penjabaran dari dua belas indikator sikap. Setiap indikator terdiri atas dua pernyataan. Dimensi dan indikator sikap bahasa dapat dilihat pada tabel 1 berikut.

Tabel 1

Dimensi dan Indikator Sikap Bahasa

\begin{tabular}{|c|c|c|}
\hline Variabel & Dimensi & Indikator \\
\hline \multirow[t]{3}{*}{ Sikap Bahasa } & $\begin{array}{l}\text { Kesetiaan Bahasa (Language } \\
\text { Loyality) }\end{array}$ & $\begin{array}{l}\text { 1. Mempertahan-kan bahasa } \\
\text { 2. Mencegah pengaruh bahasa lain } \\
\text { 3. Menggunakan bahasa pada berbagai } \\
\text { kesempatan } \\
\text { 4. Menggunakan bahasanya dalam berbagai } \\
\text { media } \\
\text { 5. Mengoleksi kesalahan penutur lain } \\
\text { bahasa tersebut yang diikuti dengan } \\
\text { membenarkan kesalahan yang terjadi } \\
\text { 6. Mengajarkan kepada generasi } \\
\text { selanjutnya agar bahasa tersebut tidak } \\
\text { punah } \\
\text { 7. Bahasa dipelihara dengan cara } \\
\text { digunakan untuk berkomunikasi dalam } \\
\text { kehidupan sehari-hari } \\
\text { 8. Penggunaan bahasa secara teratur } \\
\text { merupakan salah satu bentuk usaha } \\
\text { memperta-hankan bahasa }\end{array}$ \\
\hline & $\begin{array}{l}\text { Kebanggaan Bahasa (Language } \\
\text { Pride) }\end{array}$ & $\begin{array}{l}\text { 9. Mendorong orang mengembangkan } \\
\text { bahasa } \\
\text { 10. Menggunakan bahasa sebagai lambang } \\
\text { identitas } \\
\text { 11. Menggunakan bahasa sebagai pemersatu } \\
\text { bangsa } \\
\text { 12. Bertutur menggunakan bahasa yang } \\
\text { disukainya } \\
\text { 13. Menganggap bahasanya penting } \\
\text { 14. Percaya bahwa bahasanya dapat eksis di } \\
\text { era globalisasi }\end{array}$ \\
\hline & $\begin{array}{l}\text { Kesadaran Adanya Norma } \\
\text { (Aware-sess of The Norm) }\end{array}$ & $\begin{array}{l}\text { 15. Mendorong orang menggunakan bahasa } \\
\text { dengan cermat } \\
\text { 16. Mendorong orang menggunakan bahasa } \\
\text { dengan santun }\end{array}$ \\
\hline
\end{tabular}

Responden dipersilakan untuk menjawab salah satu dari lima pilihan jawaban dengan bobot nilai skala 5-4-32- dan 1. Pilihan jawaban dengan bobot 5 menunjukkan sikap positif responden terhadap bahasa Indonesia, sedangkan pilihan dengan bobot nilai skala 1 menunjukkan sikap negatif responden terhadap bahasa Indonesia. Angket atau kuesioner berisi pilihan sangat setuju 
(SS), setuju (S), ragu-ragu (R), tidak setuju (TS), dan sangat tidak setuju (STS) dengan rentang bobot nilai 5 -4-32- dan 1. Dari 32 pernyataan tersebut ada beberapa pernyataan yang bersifat negatif. Jadi, dalam penilaian, jawaban sangat setuju justru diberi nilai 1 dan jawaban tidak setuju justru diberi nilai 5 . Pernyataan yang bersifat negatif tersebut bernomor $9,13,15,19,21,25,26,28$, 30, 35 dan 36.

Dengan demikian, dapat dikatakan bahwa nilai bobot tinggi 5 menunjukkan sikap bahasa positif responden terhadap bahasa Indonesia. Sebaliknya, nilai rendah menunjukkan sikap negatif responden terhadap bahasa Indonesia.

\section{Teknik Analisis Data}

ini $\begin{gathered}\text { Data yang diperoleh dari penelitian } \\ \text { selanjutnya dianilisis secara }\end{gathered}$ kuantitatif berdasarkan jawaban yang dipilih responden atas kuesioner yang diberikan pada responden, lalu diberi bobot sesuai dengan skala Likert. Angket atau kuesioner terdiri atas profil responden, daftar tanyaan mengenai pengetahuan kebahasaan responden, dan pertanyaan mengenai hal-hal yang berkaitan dengan sikap bahasa.

Tahap uji statistik dilakukan sebagai tahapan akhir guna mencari korelasi variabel. Pada tahap ini, program komputer statistik SPSS (Statistics Package for Special Scientist) sangatlah diperlukan untuk mengetahui pengaruh pengetahuan kebahasaan dan sikap digunakan dua analisis statistic. Selanjutnya, dilakukan crosstabulation (analisis statistik deskriptif) untuk menjawab masalah penelitian 1 dan 2 dan menggunakan analisis jalur (korelasi dan regresi) untuk menjawab pertanyaan nomor 3 .

\section{PEMBAHASAN}

\section{Ciri Khas Objek Kajian}

Ciri khas atau karakteristik objek kajian dalam penelitian ini diambil berdasarkan batasan usia, status pernikahan, status pendidikan, bahasa pertama atau bahasa ibu yang digunakan responden, bahasa lain yang dikuasai oleh responden selain bahasa daerah atau bahasa ibu responden, serta hal-hal tentang peraturan kebahasaan.

Ciri khas atau karakteristik berdasarkan batasan usia responden diperoleh bahwa objek kajian dalam penelitian adalah 50 orang yang terdiri atas 30 responden memiliki gender lakilaki serta 20 responden memiliki gender perempuan. Dari jumlah itu, sebanyak 16 orang $(32 \%)$ berusia kurang dari 30 tahun; 15 orang $(30 \%)$ berusia $31--40$ tahun; 18 orang $(36 \%)$ berusia $41--50$ tahun; dan 1 orang (2\%) berusia lebih dari 50 tahun.

Karakteristik berdasarkan status perkawinan responden, diperoleh bahwa 42 orang $(84 \%)$ menikah dan 8 orang ((16\%) tidak/belum menikah.

Karakteristik berdasarkan pendidikan responden diperoleh bahwa responden berlatar belakang pendidikan sekolah dasar 2 orang (4\%); berpendidikan SLTP 11 orang (22\%); berpendidikan SLTA 28 orang (56\%); mereka yang berijazah diploma sebanyak lima orang (10\%); dan berpendidikan S1 4 orang (8\%).

Karakteristik berdasarkan bahasa ibu atau bahasa daerah yang digunakan responden yang bahasa pertamanya adalah bahasa Indonesia berjumlah 25 orang $(50 \%)$; bahasa pertamanya bahasa daerah berjumlah 25 orang (50\%). Sementara itu, responden yang bahasa pertamanya adalah bahasa asing tidak ditemukan dalam penelitian ini. 
Ciri khas atau karakteristik berdasarkan bahasa yang paling dikuasai selain bahasa ibu diketahui bahwa responden yang menguasai bahasa Indonesia sebanyak 25 orang $(50 \%)$; responden yang menguasai bahasa daerah ada 24 orang $(48 \%)$; dan responden yang menguasai bahasa asing ada 1 orang atau $(2 \%)$.

Ciri khas atau karakteristik berdasarkan peraturan kebahasaan dengan soal 1, yakni apakah responden mengetahui isi Pasal 36 Undang-Undang Dasar Tahun 1945, didapat data bahwa hanya 4 orang $(8 \%)$ saja yang menjawab mengetahui, sedangkan sebagian besar responden 46 orang (92\%) menjawab tidak mengetahui.

Ciri khas atau karakteristik berdasarkan peraturan kebahasaan dengan soal 2, yakni apakah responden mengetahui Undang-Undang tentang kebahasaan, yakni Undang-Undang Nomor 24 Tahun 2009 didapat data bahwa hanya 2 orang (4\%) saja yang menjawab mengetahui, sedangkan sebagian besar responden, yakni 48 orang (96\%) menjawab tidak mengetahui.

Pada soal 3, yakni apakah responden mengetahui kandungan atau isi yang terdapat pada pasal 36 UndangUndang RI Nomor 24 Tahun 2009, diketahui bahwa 2 orang (4\%) yang menjawab mengetahui, sedangkan sebagian besar responden 48 orang (96\%) menjawab tidak mengetahui.

Pada soal 4, apakah responden mengetahui kandungan atau isi yang terdapat pada Pasal 37 Undang-Undang Republik Indonesia Nomor 24 Tahun 2009, diketahui bahwa 2 orang (4\%) yang menjawab mengetahui, sedangkan sebagian besar responden 48 orang (96\%) menjawab tidak mengetahui.

Pada soal 5, apakah responden mengetahui isi Pasal 38 UU Republik Indonesia Nomor 24 Tahun 2009, diketahui bahwa sebanyak 3 responden atau $6 \%$ memberikan jawaban mengetahui, sedangkan sebagian besar responden, yakni sebanyak 47 orang (94\%) menjawab tidak mengetahui.

\section{Pengetahuan tentang Peraturan Kebahasaan}

Pengetahuan atau pemahaman mengenai ketentuan atau peraturan kebahasaan para pedagang makanan dapat diketahui melalui pertanyaan bagaimana pengetahuan pedagang makanan di Kota Metro mengenai peraturan perundang-undangan yang berkaitan dengan bahasa dan penggunaan bahasa Indonesia dan asing?

Dari hasil analisis diperoleh hasil bahwa pengetahuan atau pemahaman tentang peraturan kebahasaan para pedagang makanan di Kota Metro sangat kurang karena nilai rata-adalah 5.22 dan standar deviasi 0.932. Untuk mengetahui lebih jelas mengenai cakupan pertanyaan tersebut, diajukan 5 buah pertanyaan yang masih berkaitan dengan peraturan perundang-undangan penggunaan bahasa sebagai berikut.

Pertanyaan 1 berbunyi Apakah Bapak/Ibu mengetahui isi Pasal 36 Undang-Undang Dasar Tahun 1945? Dari 50 responden, sebanyak 46 responden atau 92\% memberikan jawaban tidak tahu dan sisanya sebanyak 4 responden atau 8\% memberikan jawaban ya. Hasil tersebut menunjukkan bahwa pengetahuan para pedagang makanan di Kota Metro mengenai peraturan kebahasaan, khususnya yang berkaitan dengan Pasal 36 UndangUndang Dasar Tahun 1945 masih sangat kurang karena hanya sebagian kecil, yakni $8 \%$ responden yang menjawab tahu.

Pertanyaan 2 berbunyi, Apakah Bapak/Ibu mengetahui Undang-Undang 
Nomor 24 Tahun 2009? Dari 50 responden, diketahui bahwa 48 responden atau $96 \%$ memberikan jawaban tidak tahu dan sisanya hanya 2 responden atau sebanyak $4 \%$ memberikan jawaban ya. Hal ini menunjukkan bahwa pengetahuan pedagang makanan di Kota Metro mengenai peraturan kebahasaan, khususnya yang berkaitan dengan UU Nomor 24 Tahun 2009 masih sangat kurang karena hanya sebagian kecil atau $4 \%$ responden yang memberikan jawaban tahu. Pertanyaan 3 berbunyi, Apakah Bapak/Ibu mengetahui isi Pasal 36 UU Nomor 24 Tahun 2009? Dari 50 orang responden, diketahui bahwa 48 responden atau (96\%) memberikan jawaban tidak tahu dan sisanya, yakni hanya 2 responden atau $4 \%$ memberikan jawaban ya. Hal ini menunjukkan bahwa pengetahuan pedagang makanan di Kota Metro mengenai peraturan kebahasaan, khususnya berkaitan dengan isi Pasal 36 UU Nomor 24 Tahun 2009? masih sangat kurang karena hanya sebagian kecil responden atau $4 \%$ yang memberikan jawaban tahu.

Pertanyaan 4 berbunyi, Apakah Bapak/Ibu mengetahui isi Pasal 37 Undang-Undang Nomor 24 Tahun 2009? Dari 50 responden, diketahui bahwa 48 responden atau 96\% memberikan jawaban tidak tahu dan sisanya hanya 2 responden atau $4 \%$ memberikan jawaban ya. Hal tersebut memperlihatkan bahwa pengetahuan pedagang makanan di Kota Metro mengenai peraturan kebahasaan, khususnya berkaitan dengan isi Pasal 37 Undang-Undang Nomor 24 Tahun 2009 masih sangat kurang karena hanya sebagian kecil, yakni (4\%), responden yang menjawab tahu.

Pertanyaan 4 berbunyi, Apakah Bapak/Ibu mengetahui isi Pasal 38 Undang-Undang Nomor 24 Tahun 2009? Dari 50 responden, diketahui bahwa 47 responden atau 94\% memberikan jawaban tidak tahu dan sisanya, yakni hanya 2 responden atau $4 \%$, memberikan jawab $y a$, sedangkan 1 responden atau $2 \%$ tidak menjawab. Ini menunjukkan bahwa pengetahuan pedagang makanan di Kota Metro mengenai peraturan kebahasaan, khususnya yang berkaitan dengan isi Pasal 38 Undang-Undang Nomor 24 Tahun 2009 masih sangat kurang karena hanya sebagian kecil responden, yakni $4 \%$, yang memberikan jawaban tahu.

\section{Sikap Bahasa}

Informasi mengenai sikap bahasa para pedagang makanan diperoleh melalui pertanyaan bagaimana sikap pedagang makanan di Kota Metro terhadap bahasa dan penggunaan bahasa Indonesia dan asing? Berdasarkan perhitungan statistik (SPSS versi 17) dan hasil analisis, diperoleh informasi bahwa sikap dalam berbahasa para pedagang makanan di Kota Metro terhadap pemakaian bahasa Indonesia dan bahasa asing memiliki rata-rata skor 139.86 dan standar deviasi $9.737 \%$. Hal itu berarti bahwa sikap bahasa pedagang makanan di Kota Metro dapat dikategorikan sangat baik karena diperoleh hasil pada nilai rata-ratanya yang sudah mencapai $39.86 \%$.

Untuk mengetahui lebih jelas mengenai cakupan pertanyaan bagaimana sikap pedagang makanan di Kota Metro terhadap bahasa dan penggunaan bahasa Indonesia dan asing diajukan 36 buah pernyataan di dalam angket dengan rincian sebagai berikut.

Pertanyataan 1 berbunyi, bahasa Indonesia sebagai bahasa negara, yakni bahasa resmi kenegaraan, transaksi, dan dokumentasi niaga, serta pengembangan ilmu pengetahuan harus saya pertahankan. Dari 50 responden, diketahui bahwa ada 14 responden atau 
$28 \%$ yang memberikan jawaban setuju serta 36 responden atau $72 \%$ yang memberikan jawaban sangat setuju. Sementara itu, tidak terdapat satu responden pun yang memberikan jawaban sangat tidak setuju, tidak setuju, serta ragu-ragu tidak ada satu pun. Keadaan tersebut memperlihatkan bahwa kebanyakan reponden menyatakan pendapat setuju dan sangat setuju dengan pernyataan bahasa Indonesia sebagai bahasa negara, yakni bahasa resmi kenegaraan, transaksi, dan dokumentasi niaga, serta pengembangan ilmu pengetahuan harus saya pertahankan.

Pertanyaan 2 berbunyi, bahasa Indonesia sebagai bahasa nasional, yakni bahasa pemersatu, sarana komunikasi dan jati diri bangsa, harus saya pertahanakan. Dari hasil analisis diketahui bahwa dari 50 responden, ada 15 responden atau $30 \%$ yang memberikan jawaban setuju dan 35 responden atau $70 \%$ yang memberikan jawaban sangat setuju. Sementara itu, tidak ada satu pun responden yang memberikan jawaban sangat tidak setuju, tidak setuju, dan ragu-ragu. Hal ini menunjukkan bahwa sebagian besar responden menyatakan setuju dan sangat setuju dengan pernyataan saya harus mempertahankan bahasa Indonesia sebagai bahasa nasional (bahasa pemersatu, sarana komunikasi, dan jati diri bangsa).

Pertanyaan 3 berbunyi, istilah asing akan saya terjemahkan ke dalam istilah bahasa Indonesia di dalam lingkungan bisnis atau usaha saya. Dari 50 responden, diketahui bahwa ada 49 responden yang memberikan jawaban pertanyaan tersebut, sedangkan 1 responden tidak memberikan jawaban. Adapun perincian jawaban responden terhadap pernyataan sikap bahasa 3 adalah 1 responden atau $2 \%$ memberikan jawaban sangat tidak setuju, 3 responden atau $6 \%$ memberikan jawaban tidak setuju, 8 responden atau $16 \%$ memberikan jawaban ragu-ragu, 34 responden atau $68 \%$ memberikan jawaban setuju, dan 3 responden atau 6\% memberikan jawaban sangat setuju.

Pertanyaan 4 berbunyi, istilah atau bahasa daerah akan saya terjemahkan/padankan ke dalam istilah bahasa Indonesia di dalam lingkungan usaha atau bisnis saya. Dari 50 responden diketahui bahwa bahwa tidak ada satu pun responden atau $0 \%$ yang memberikan jawaban sangat tidak setuju, 1 responden atau 2\% memberikan jawaban tidak setuju, 8 responden atau $16 \%$ memberikan jawaban ragu-ragu, 37 responden atau $74 \%$ yang memberikan jawaban setuju, dan sisanya, yakni 4 responden atau $8 \%$ memberikan jawaban sangat setuju. Ini menunjukkan bahwa sebagian besar responden menyatakan setuju dengan pernyataan istilah atau bahasa daerah akan saya terjemahkan/padankan ke dalam istilah bahasa Indonesia di dalam lingkungan usaha atau bisnis saya.

Pertanyaan 5 berbunyi, istilah bahasa Indonesia akan saya pilih daripada istilah bahasa asing. Dari 50 responden didapat hasil bahwa tidak seorang pun responden atau $0 \%$ yang memberikan jawaban sangat tidak setuju dan sangat setuju. Sementara itu, 2 responden atau $4 \%$ memberikan jawaban ragu-ragu, 34 responden atau $68 \%$ memberikan jawaban setuju, dan sisanya 14 responden atau $28 \%$ memberikan jawaban sangat setuju. Hal ini menunjukkan bahwa sebagian besar responden menyatakan setuju dan sangat setuju dengan pernyataan Saya akan memilih istilah bahasa Indonesia daripada bahasa asing.

Pertanyaan 6 berbunyi, istilah bahasa Indonesia akan saya pilih daripada istilah bahasa daerah. Dari 50 responden didapat hasil bahwa tidak 
seorang pun responden atau 0\% yang memberikan jawaban sangat tidak setuju, 3 responden atau $6 \%$ memberikan jawaban tidak setuju, sementara 5 responden atau 10\% memberikan jawaban ragu-ragu, 33 responden atau $66 \%$ memberikan jawaban setuju, dan sisanya 9 responden atau $18 \%$ memberikan jawaban sangat setuju. Hal ini menunjukkan bahwa sebagian besar responden menyatakan setuju dan sangat setuju dengan pernyataan istilah bahasa Indonesia akan saya pilih daripada istilah bahasa daerah.

Pertanyaan 7 berbunyi, penggunaan bahasa Indonesia di tempat usaha saya lebih saya utamakan. Dari 50 responden diperoleh hasil bahwa tidak satu pun responden atau $0 \%$ yang memberikan jawaban sangat tidak setuju, 1 responden atau $2 \%$ yang memberikan jawaban tidak setuju, sementara 2 responden atau 4\% memberikan jawaban ragu-ragu, 38 responden atau $76 \%$ memberikan jawaban setuju, dan sisanya 9 responden atau $18 \%$ memberikan jawaban sangat setuju. Hal ini menunjukkan bahwa sebagian besar responden menyatakan setuju dan sangat setuju dengan pernyataan penggunaan bahasa Indonesia di tempat usaha saya lebih saya utamakan.

Pertanyaan 8 berbunyi, bahasa Indonesia saya gunakan dalam berkomunikasi dengan teman bisnis yang bisa berbahasa Indonesia. Dari 50 responden diketahui bahwa tidak satu pun responden atau 0\% memberikan jawaban sangat tidak setuju dan tidak setuju. Sementara itu, 5 responden atau $10 \%$ memberikan jawaban ragu-ragu, 36 responden atau $72 \%$ memberikan jawaban setuju, dan sisanya, yakni 9 responden atau $18 \%$ memberikan jawaban sangat setuju. Ini menunjukkan bahwa sebagian besar responden menyatakan setuju dan sangat setuju dengan pernyataan bahasa Indonesia saya gunakan dalam berkomunikasi dengan teman bisnis yang bisa berbahasa Indonesia.

Pertanyaan 9 berbunyi, Saya menggunakan bahasa Indonesia dalam berkomunikasi dengan rekan usaha yang dapat berbahasa Indonesia. Dari 50 responden yang dijadikan sampel, didapat hasil bahwa ada satu responden atau $2 \%$ yang memberikan jawaban sangat tidak setuju, 17 responden atau $34 \%$ yang memberikan jawaban tidak setuju, 8 responden atau $16 \%$ yang memberikan jawaban ragu-ragu, 20 responden atau $40 \%$ yang memberikan jawaban setuju, serta 4 responden atau $8 \%$ yang memberikan jawaban sangat. Hal ini menunjukkan bahwa sebagian besar responden menyatakan setuju dan ragu-ragu dengan pernyataan Saya menggunakan bahasa Indonesia dalam berkomunikasi dengan rekan usaha yang dapat berbahasa Indonesia.

Pertanyaan 10 berbunyi, bahasa Indoensia saya gunakan di dalam penulisan penamaan tempat bisnis pada kain rentang/banner. Dari 50 responden diketahui bahwa tidak satu pun responden atau $0 \%$ yang memberikan jawaban sangat tidak setuju dan tidak setuju. Sementara itu, hanya 2 responden atau $4 \%$ yang memberikan jawaban ragu-ragu, 36 responden atau $72 \%$ yang memberikan jawaban setuju, dan 12 responden atau $24 \%$ yang memberikan jawaban sangat setuju. Hal ini menunjukkan bahwa sebagian besar responden menyatakan setuju dan sangat setuju dengan pernyataan bahasa Indoensia saya gunakan di dalam penulisan penamaan tempat bisnis pada kain rentang/banner.

Pertanyaan 11 berbunyi, bahasa Indonesia saya gunakan di dalam penulisan mепи di dalam usaha saya. Dari 50 responden didapat hasil bahwa tidak satu pun responden atau $0 \%$ yang 
memberikan jawaban sangat tidak setuju, tidak setuju, dan ragu-ragu. Sementara itu, 39 responden atau $78 \%$ memberikan jawaban setuju, dan sisanya, yakni 10 responden atau $20 \%$ memberikan jawaban sangat setuju. Namun, dari penelitian ini didapat 1 responden atau $2 \%$ yang tidak memberikan jawaban. Hal ini menunjukkan bahwa sebagian besar responden menyatakan setuju dan sangat setuju dengan pernyataan bahasa Indonesia saya gunakan di dalam penulisan menu di dalam usaha saya.

Pertanyaan 12 berbunyi, bahasa Indonesia saya gunakan di dalam nota transaksi. Dari 50 responden diketahui bahwa tidak satu pun responden atau 0\% memberikan jawaban sangat tidak setuju dan tidak setuju. Sementara itu, hanya 2 responden atau 4\% yang memberikan jawaban ragu-ragu, 37 responden atau $74 \%$ yang memberikan jawaban sangat setuju, serta sisanya 11 responden atau $22 \%$ yang memberikan jawaban sangat setuju. Hal ini menunjukkan bahwa sebagian besar responden menyatakan setuju dan sangat setuju dengan pernyataan bahasa Indonesia saya gunakan di dalam nota transaksi.

Pertanyaan 13 berbunyi, kesalahan penggunaan bahasa para pekerja di tempat bisnis saya tidak saya koreksi. Dari 50 responden diketahui bahwa ada 3 responden atau $6 \%$ yang memberikan jawaban sangat tidak setuju, 21 responden atau $42 \%$ yang memberikan jawaban tidak setuju. Sementara itu, ada 7 responden atau $14 \%$ yang memberikan jawabab ragu-ragu, serta 19 responden atau $38 \%$ yang memberikan jawaban setuju. Akan tetapi, tidak satu pun responden atau $0 \%$ yang memberikan jawaban sangat setuju. Hal ini menunjukkan bahwa sebagian besar responden memberikan pendapat setuju dan tidak setuju terhadap pernyataan kesalahan penggunaan bahasa para pekerja di tempat bisnis saya tidak saya koreksi.

Pertanyaan 14 berbunyi, jika para pekerja atau karyawan saya melakukan kesalahan dalam penggunaan bahasa, saya memberi tahu mereka. Dari 50 responden diketahui bahwa tidak satu pun responden atau $0 \%$ yang memberikan jawaban sangat tidak setuju, 7 responden atau $14 \%$ yang memberikan jawaban tidak setuju. Sementara itu, terdapat 5 responden atau $10 \%$ yang memberikan jawaban raguragu, 32 responden atau $64 \%$ yang memberikan jawaban setuju, dan 1 responden atau $2 \%$ yang tidak memberikan jawaban. Hal ini menunjukkan bahwa sebagian besar responden menyatakan setuju dengan pernyataan jika para pekerja atau karyawan saya melakukan kesalahan dalam penggunaan bahasa, saya memberi tahu mereka.

Pertanyaan 15 berbunyi, keluarga saya saya anjurkan untuk menggunakan bahasa daerah. Dari 50 responden diketahu bahwa ada satu responden atau $2 \%$ yang memberikan jawaban sangat tidak setuju, 15 responden atau 30\% yang memberikan jawaban tidak setuju. Sementara itu, 6 responden atau 12\% yang membrikan jawaban ragu-ragu, 27 responden atau $44 \%$ memberikan jawaban setuju, dan 1 responden atau 2\% memberikan jawaban sangat setuju.Hal ini menunjukkan bahwa sebagian besar responden menyatakan setuju dengan pernyataan keluarga saya saya anjurkan untuk menggunakan bahasa daerah.

Pertanyaan 16 berbunyi, cara saya dalam memelihara bahasa Indonesia adalah menggunakan bahasa itu di dalam berkomunikasi dengan lingkungan keluarga saya. Dari 50 responden diketahui bahwa tidak satu pun responden atau $0 \%$ yang memberikan jawaban sangat tidak setuju, 15 responden atau 30\% yang 
memberikan jawaban tidak setuju. Sementara itu, 3 responden atau 6\% memberikan jawaban ragu-ragu, 33 responden atau $66 \%$ memberikan jawaban setuju, dan 9 responden atau $18 \%$ memberikan jawaban sangat setuju. Hal ini menunjukkan bahwa sebagian besar responden menyatakan setuju dan sangat setuju dengan pernyataan cara saya dalam memelihara bahasa Indonesia adalah menggunakan bahasa itu di dalam berkomunikasi dengan lingkungan keluarga saya.

Pertanyaan 17 berbunyi, bahasa Indonesia saya pelihara dengan cara menggunakan bahasa itu di dalam berkomunikasi di dalam lingkungan sosial. Dari 50 responden diketahui bahwa tidak satu pun responden atau $0 \%$ yang memberikan jawaban sangat tidak setuju dan tidak setuju, 3 responden atau $6 \%$ yang memberikan jawaban raguragu, 36 responden atau $72 \%$ yang memberikan jawaban setuju, dan 11 responden atau $22 \%$ yang memberikan jawaban sangat setuju. Hal ini menunjukkan bahwa sebagian besar responden menyatakan setuju dan sangat setuju dengan pernyataan bahasa Indonesia saya pelihara dengan cara menggunakan bahasa itu di dalam berkomunikasi di dalam lingkungan sosial.

Pertanyaan 18 berbunyi, untuk mempertahankan bahasa Indonesia sebagai bahasa nasional, yakni bahasa persatuan, sarana komunikasi dan jati diri bangsa, saya selalu menggunakan bahasa itu secara teratur. Dari 50 responden diketahui bahwa tidak satu pun responden atau $0 \%$ yang memberikan jawaban sangat tidak setuju, 3 responden atau $6 \%$ yang memberikan jawaban tidak setuju, tidak satu pun responden atau $0 \%$ yang memberikan jawaban ragu-ragu, 25 responden atau $50 \%$ yang memberikan jawaban setuju, dan 22 responden atau
44\% yang memberikan jawaban sangat setuju. Hal ini menunjukkan bahwa sebagian besar responden menyatakan setuju dan sangat setuju dengan pernyataan untuk mempertahankan bahasa Indonesia sebagai bahasa nasional, yakni bahasa persatuan, sarana komunikasi dan jati diri bangsa, saya selalu menggunakan bahasa itu secara teratur.

Pertanyaan 19 berbunyi, para pekerja di tempat bisnis saya saya beri motivasi untuk lebih mempelajari bahasa asing daripada bahasa Indonesia. Dari 50 responden diketahui bahwa ada 5 responden atau $10 \%$ yang memberikan jawaban sangat tidak setuju, 34 responden atau 68\% yang memberikan jawaban tidak setuju. Sementara itu, ada 5 responden atau $10 \%$ yang memberikan jawaban ragu-ragu, dan 6 responden atau $12 \%$ yang memberikan jawaban setuju. Sementara itu, tidak ada satu pun responden atau $0 \%$ yang memberikan jawaban sangat setuju. Hal ini menunjukkan bahwa sebagian besar responden menyatakan tidak setujudengan pernyataan para pekerja di tempat bisnis saya saya beri motivasi untuk lebih mempelajari bahasa asing daripada bahasa Indonesia.

Pertanyaan 20 berbunyi, bahasa Indonesia akan saya gunakan ketika saya berkomunikasi dengan para pelanggan atau konsumen. Dari 50 responden diketahui bahwa tidak ada satu pun responden atau $0 \%$ yang memberikan jawaban sangat tidak setuju. Sementara itu, 3 responden atau $6 \%$ yang memberikan jawaban tidak setuju, 2 responden atau $4 \%$ yang memberikan jawaban ragu-ragu, 39 responden atau $78 \%$ yang memberikan jawaban setuju, dan 6 responden atau $12 \%$ yang memberikan jawaban sangat setuju. Hal ini menunjukkan bahwa sebagian besar responden menyatakan 
setuju dan sangat setuju dengan pernyataan bahasa Indonesia akan saya gunakan ketika saya berkomunikasi dengan para pelanggan atau konsumen.

Pertanyaan 21 berbunyi, bahasa daerah akan saya gunakan ketika saya berkomunikasi dengan para pelanggan atau konsumen. Dari 50 responden diketahui bahwa tidak ada satu pun responden atau $0 \%$ yang memberikan jawaban sangat tidak setuju, 14 responden atau $28 \%$ yang memberikan jawaban tidak setuju. Sementara itu, 8 responden atau $16 \%$ yang memberikan jawaban ragu-ragu, 27 responden atau $54 \%$ yang memberikan jawaban setuju, dan 1 responden atau $2 \%$ yang memberikan jawaban sangat setuju. Hal ini menunjukkan bahwa sebagian besar responden menyatakan setuju dengan pernyataan bahasa daerah akan saya gunakan ketika saya berkomunikasi dengan para pelanggan atau konsumen.

Pertanyaan 22 berbunyi, ketika berkomunikasi dengan orang lain yang berbeda suku, saya nyaman dalam menggunakan bahasa Indonesia. Dari 50 responden diketahui bahwa tidak ada satu pun responden atau (0\%) yang memberikan jawaban sangat tidak setuju, 2 responden atau $4 \%$ yang memberikan jawaban tidak setuju. Sementara itu, 1 responden atau 2\% yang memberikan jawaban ragu-ragu, 34 responden atau $68 \%$ yang memberikan jawaban setuju, dan sisanya 13 responden atau $26 \%$ yang memberikan jawaban sangat setuju. Hal ini menunjukkan bahwa sebagian besar responden menyatakan setuju dengan pernyataan ketika berkomunikasi dengan orang lain yang berbeda suku, saya nyaman dalam menggunakan bahasa Indonesia.

Pertanyaan 23 berbunyi, bahasa Indonesia digunakan di berbagai daerah di Indonesia membuat saya merasa senang. Dari 50 responden diketahui bahwa tidak ada satu pun responden atau $0 \%$ yang memberikan jawaban sangat tidak setuju dan tidak setuju. Sementara itu, 1 responden atau $2 \%$ yang memberikan jawaban ragu-ragu, 22 responden atau $44 \%$ yang memberikan jawaban setuju, dan 27 responden atau $54 \%$ yang memberikan jawaban sangat setuju. Hal ini menunjukkan bahwa sebagian besar responden menyatakan setuju dan sangat setuju dengan pernyataan bahasa Indonesia digunakan di berbagai daerah di Indonesia membuat saya merasa senang.

Pertanyaan 24 berbunyi, di tempat usaha saya, saya lebih suka memakai bahasa Indonesia di dalam berkomunikasi. Dari 50 responden diketahui bahwa tidak ada satu pun responden atau 0\% yang menjawab sangat tidak setuju dan ragu-ragu. Sementara itu, 6 responden atau 12\% yang memberikan jawaban tidak setuju, 34 responden atau $68 \%$ yang memberikan jawaban setuju, dan 10 responden atau $20 \%$ yang memberikan jawaban sangat setuju. Hal ini menunjukkan bahwa sebagian besar responden menyatakan setuju dan sangat setuju dengan pernyataan di tempat usaha saya, saya lebih suka memakai bahasa Indonesia di dalam berkomunikasi.

Pertanyaan 25 berbunyi, di tempat usaha saya, saya lebih suka memakai bahasa daerah di dalam berkomunikasi. Dari 50 responden diketahui bahwa ada 2 responden atau $4 \%$ yang memberikan jawaban sangat tidak setuju. Sementara itu, 23 responden atau $46 \%$ yang memberikan jawaban tidak setuju, 8 responden atau $16 \%$ yang memberikan jawaban ragu-ragu, 16 responden atau $32 \%$ yang memberikan jawaban setuju, dan hanya 1 responden atau $2 \%$ yang memberikan jawaban sangat setuju. Hal ini menunjukkan bahwa sebagian besar responden menyatakan tidak setuju 
dengan pernyataan di tempat usaha saya, saya lebih suka memakai bahasa daerah di dalam berkomunikasi.

Pertanyaan 26 berbunyi, di tempat usaha saya, saya lebih suka memakai bahasa asing di dalam berkomunikasi. Dari 50 responden diketahui bahwa ada 13 responden atau $26 \%$ yang memberikan jawaban sangat tidak setuju, 34 responden atau 68\% yang memberikan jawaban tidak setuju, 2 responden atau $4 \%$ yang memberikan jawaban ragu-ragu, hanya 1 responden atau $2 \%$ yang memberikan jawaban setuju. Sementara itu, tidak ada satu pun responden atau $0 \%$ yang memberikan jawaban sangat setuju. Hal ini menunjukkan bahwa sebagian besar responden menyatakan tidak setuju dan sangat tidak setuju terhadap pernyataan di tempat usaha saya, saya lebih suka memakai bahasa asing di dalam berkomunikasi.

Pertanyaan 27 berbunyi, saat berkomunikasi dengan teman bisnis yang bisa berbahasa Indonesia, saya lebih suka menggunakan bahasa Indonesia. Dari 50 responden diketahui bahwa tidak ada satu pun responden atau $0 \%$ yang memberikan jawaban sangat tidak setuju dan tidak setuju. Sementara itu, 7 responden atau $14 \%$ yang memberikan jawaban ragu-ragu, 37 responden atau $74 \%$ yang memberikan jawaban setuju, dan 6 responden atau $12 \%$ yang memberikan jawaban sangat setuju. Hal ini menunjukkan bahwa sebagian besar responden menyatakan setuju dengan pernyataan saat berkomunikasi dengan teman bisnis yang bisa berbahasa Indonesia, saya lebih suka menggunakan bahasa Indonesia.

Pertanyaan 28 berbunyi, saat berkomunikasi dengan teman bisnis yang bisa berbahasa Indonesia, saya lebih suka menggunakan bahasa daerah. Dari 50 responden diketahui bahwa tidak ada satu pun responden atau $0 \%$ yang memberikan jawaban sangat tidak setuju. Sementara itu, 15 responden atau $30 \%$ yang memberikan jawaban tidak setuju, 9 responden atau $18 \%$ yang memberikan jawaban ragu-ragu, 23 responden atau $48 \%$ yang memberikan jawaban setuju, dan 3 responden atau 6\% yang memberikan jawaban sangat setuju. Hal ini menunjukkan bahwa sebagian besar responden menyatakan setuju dengan pernyataan saat berkomunikasi dengan teman bisnis yang bisa berbahasa Indonesia, saya lebih suka menggunakan bahasa daerah.

Pertanyaan 29 berbunyi, dalam bidang bisnis saya, bahasa Indonesia lebih penting daripada bahasa daerah. Dari 50 responden diketahui bahwa ada satu (2\%) responden yang menjawab sangat tidak setuju, 7 responden atau $14 \%$ yang memberikan jawaban tidak setuju, 5 responden atau $10 \%$ yang memberikan jawaban ragu-ragu, 30 responden atau $60 \%$ yang memberikan jawaban setuju, serta 7 responden atau $14 \%$ yang memberikan jawaban sangat setuju. Hal ini menunjukkan bahwa sebagian besar responden menyatakan setuju dengan pernyataan dalam bidang bisnis saya, bahasa Indonesia lebih penting daripada bahasa daerah.

Pertanyaan 30 berbunyi, menurut pendapat saya, dalam kehidupan sosial bahasa Indonesia tidak terlalu penting. Dari 50 responden diketahui bahwa ada 19 responden atau $38 \%$ yang memberikan jawaban sangat tidak setuju, 29 responden atau 58\% memberikan jawaban tidak setuju, serta 2 responden atau $4 \%$ yang memberikan jawaban ragu-ragu. Sementara itu, tidak ada satu pun responden yang memberikan pilihan jawaban setuju dan tidak setuju. Hal ini menunjukkan bahwa sebagian besar responden menyatakan setuju dengan pernyataan menurut 
pendapat saya, dalam kehidupan sosial bahasa Indonesia tidak terlalu penting.

Pertanyaan 31 berbunyi, saya merasa yakin bahwa bahasa Indonesia dapat menjadi bahasa internasional. Dari 50 responden diketahui bahwa tidak ada satu pun responden atau $0 \%$ yang memberikan jawaban sangat tidak setuju. Sementara itu, 3 responden atau $6 \%$ yang memberikan jawaban tidak setuju, 7 responden atau $14 \%$ yang memberikan jawaban ragu-ragu, 33 responden atau $66 \%$ yang memberikan jawaban setuju, dan sisanya 7 responden atau $14 \%$ yang memberikan jawaban sangat setuju. Hal ini menunjukkan bahwa sebagian besar responden menyatakan setuju dengan pernyataan saya merasa yakin bahwa bahasa Indonesia dapat menjadi bahasa internasional.

Pertanyaan 32 berbunyi, lebih mudah mempelajari bahasa Indonesia daripada bahasa daerah. Dari 50 responden diketahui bahwa ada satu responden atau $2 \%$ yang memberikan jawaban sangat tidak setuju dan tidak setuju, tidak ada satu pun responden atau $0 \%$ yang memberikan jawaban raguragu. Sementara itu, 33 responden atau $66 \%$ yang memberikan jawaban setuju, 14 responden atau $28 \%$ yang memberikan jawaban sangat setuju, serta 1 responden atau $2 \%$ yang tidak memberikan jawaban sama sekali. Sebagian besar responden menyatakan setuju dengan pernyataan lebih mudah mempelajari bahasa Indonesia daripada bahasa daerah.

Pertanyaan 33 berbunyi, dalam menggunakan bahasa Indonesia, kaidah bahasanya selalu saya perhatikan dengan benar. Dari 50 responden diketahui bahwa tidak ada satu pun responden atau $0 \%$ yang memberikan jawaban sangat tidak setuju. Sementara itu,1 responden atau $2 \%$ yang memberikan jawaban tidak setuju, 6 responden atau $12 \%$ yang memberikan jawaban ragu-ragu, 38 responden atau $76 \%$ yang memberikan jawaban setuju, dan sisanya 5 responden atau $10 \%$ yang memberikan jawaban sangat setuju. Hal ini menunjukkan bahwa sebagian besar responden menyatakan setuju dengan pernyataan dalam menggunakan bahasa Indonesia, kaidah bahasanya selalu saya perhatikan dengan benar.

Pertanyaan 34 berbunyi, para pegawai saya saya anjurkan untuk memakai bahasa Indonesia secara baik dan benar. Dari 50 responden diketahui bahwa tidak ada satu pun responden atau $0 \%$ yang memberikan jawaban sangat tidak setuju. Sementara itu, 2 responden atau $4 \%$ yang memberikan jawaban tidak setuju, 2 responden atau $4 \%$ yang memberikan jawaban ragu-ragu, 39 responden atau $78 \%$ yang memberikan jawaban setuju, dan sisanya 7 responden atau $14 \%$ yang memberikan jawaban sangat setuju. Hal ini menunjukkan bahwa sebagian besar responden menyatakan setuju dengan pernyataan para pegawai saya saya anjurkan untuk memakai bahasa Indonesia secara baik dan benar.

Pertanyaan 35 berbunyi, jika teman bisnis saya tidak menggunakan bahasa secara santun, saya tidak memedulikannya. Dari 50 responden diketahui bahwa ada 11 responden atau $22 \%$ yang memberikan jawaban sangat tidak setuju. Sementara itu, populasi paling banyak, yakni 35 responden atau $70 \%$ yang memberikan jawaban tidak setuju, 2 responden atau $4 \%$ yang memberikan jawaban ragu-ragu, serta sisanya 2 responden atau $4 \%$ yang memberikan jawaban setuju, dan tidak satu pun responden atau $0 \%$ yang memberikan jawaban sangat setuju. Hal ini menunjukkan bahwa sebagian besar responden menyatakan tidak setuju dengan pernyataan jika teman bisnis 
saya tidak menggunakan bahasa secara santun, saya tidak memedulikannya.

Pertanyaan 36 berbunyi, jika para pegawai atau karyawan saya tidak menggunakan bahasa secara santun, saya tidak memedulikannya. Dari 50 responden diketahui bahwa ada 10 responden atau $20 \%$ yang memberikan jawaban sangat tidak setuju. Sementara itu, populasi paling banyak, yakni 36 responden atau $72 \%$ yang memberikan jawaban tidak setuju, 4 responden atau $8 \%$ yang memberikan jawaban setuju. Sementara, untuk pilihan ragu-ragu dan sangat setuju, diketahui bahwa tidak ada satu pun responden atau $0 \%$ yang memilih kedua pilihan tersebut. Hal ini menunjukkan bahwa sebagian besar responden menyatakan tidak setuju dengan pernyataan jika para pegawai atau karyawan saya tidak menggunakan bahasa secara santun, saya tidak memedulikannya.

\section{Pengaruh Pengetahuan Kebahasaaan Terhadap Sikap Bahasa}

Informasi mengenai pengaruh pengetahuan kebahasaa terhadap sikap bahasa dapat diketahui melalui pertanyaan Apakah pengetahuan tentang peraturan kebahasaan berpengaruh terhadap sikap bahasa pedagang makanan di Kota Metro?

Dari hasil analisis diketahui bahwa pengetahuan tentang peraturan kebahasaan tidak berpengaruh terhadap sikap bahasa pedagang makanan di Kota Metro. Hal ini dapat dilihat dari hasil penghitungan statistik SPSS versi 17 diperoleh angka signifikan 0.65, yang berarti tidak terdapat pengaruh peraturan kebahasaan terhadap sikap bahasa.

\section{PENUTUP}

Dari hasil analisis diperoleh simpulan sebagai berikut. Pengetahuan tentang Peraturan Kebahasaan pedagang makanan di Kota Metro adalah rata-rata skor $5.22 \%$ dan standar deviasi $0.932 \%$. Hasil penelitian ini menunjukkan bahwa pengetahuan tentang Peraturan Kebahasaan para pedagang makanan di Kota Metro dapat dikategorikan sangat kurang karena nilai rata-ratanya hanya mencapai $5.22 \%$. Hal ini berarti bahwa pedagang makanan di Kota Metro sangat kurang pengetahuan dalam hal peraturan perundang-undangan yang berkaitan dengan bahasa dan penggunaan bahasa Indonesia dan asing.

1. Sikap bahasa pedagang makanan di Kota Metro terhadap penggunaan bahasa Indonesia dan asing memiliki rata-rata skor 139.86 serta standar deviasi 9.737\%. Skor tersebut menunjukkan bahwa sikap bahasa pedagang makanan di Kota Metro dapat dikategorikan sangat baik karena nilai rata-ratanya sudah mencapai 139.86. Dengan demikian, dapat diberikan simpulan bahwa sikap bahasa pedagang makanan di Kota Metro sangat baik.

2. Pengetahuan pedagang makanan di Kota Metro mengenai peraturan perundang-undangan yang berkaitan dengan bahasa dan penggunaan bahasa Indonesia serta bahasa asing dapat disimpulkan bahwa peraturan kebahasaan sangat tidak berpengaruh terhadap sikap bahasa seseorang. Sikap bahasa hanya dipengaruhi sebesar 0.004 persen dari sampel (50 responden), sisanya dipengaruhi oleh faktor-faktor lain.

3. Faktor lain yang memengaruhi harus dapat dibuktikan melalui kajian-kajian dalam penelitian selanjutnya. 
Saran yang dapat diberikan dari hasil kajian dalam penelitian ini adalah bahwa kita harus mengembangkan sikap positif terhadap bahasa Indonesia. Hal ini merupakan langkah atau upaya pembinaan dan pengembangan sikap dan rasa bangga masyarakat Indonesia dalam memiliki dan menggunakan bahasa Indonesia. Melalui sikap positif tersebut, diharapkan bahwa bahasa Indonesia dapat terus ditingkatkan penggunaannya. Dengan demikian, pemertahanan terhadap bahasa Indonesia dapat terus berlangsung. Selain itu, jika masyarakat Indonesia dihadapkan pada pilihan menggunakan bahasa Indonesia atau bahasa asing, sikap dalam berbahasa untuk 1) lebih mendahulukan dan mengutamakan bahasa Indonesia, 2) jika telah terdapat padanan dalam bahasa Indonesia lebih mendahulukan pemakaiannya, 3) bahasa Indonesia harus menjadi "ladang bahasa bersama" yang harus dikelola, dikembangkan, dan dimajukan, tentu saja akan dimiliki

Penelitian lebih lanjut perlu dilakukan untuk mengetahui motivasimotivasi yang menyebabkan para pedagang makanan memakai bahasa asing, terutama bahasa Inggris. Apakah terjadinya hal tersebut disebabkan oleh tidak adanya sanksi bagi pedagang makanan yang memakai bahasa asing di ruang publik, kurangnya penghargaan dari pemerintah bagi mereka yang mengutamakan pemakaian bahasa Indonesia, ataukah faktor ekonomi dan martabat mereka dalam penggunaan bahasa asing.

\section{DAFTAR PUSTAKA}

A'ini, Q, Sumarlam, Djatmika. (2018) Fungsi kepatuhan maksim prinsip kesantunan pada komentar berita di fanspage facebook Merdeka.Com. Kandai 14(1), 3144 (DOI.1026499/jk.v14i1.575)
Chaer, A. \& Leonie A. (2010). Sosiolinguistik: Perkenalan awal. Jakarta: PT Rineka Cipta.

Echols, J. M. \& Hassan S. (2003). Kamus Inggris-Indonesia. An English-Indonesian Dictionary. Cetakan XXV. Jakarta: PT. Gramedia.

Fishman. J. A. (1964). Language maintenance and language shift as field of inquiry: A definition of the field and suggestions for its further development. Linguistic: Volume 2(9), 32-70. Published: on line.

Halim, A. (1983). Sikap bahasa dan pelaksanaan kebijaksanaan bahasa nasional. Jakarta: Depdikbud.

Isnaeni, M. et.al. (2015). Sikap bahasa masyarakat Lampung terhadap bahasa Lampung. Laporan Penelitian. Kantor Bahasa Provinsi Lampung.

Lucas, C. (2004). The sociolinguistics of sign languages. Great Britain: Cambridge University Press.

Mahsun (2005). Metode penelitian bahasa: Tahapan strategi, metode, dan tekniknya. Jakarta: PT Raja Grafindo Persada.

Badan Bahasa, Depdiknas. (2014). Kamus besar bahasa Indonesia pusat bahasa, Edisi Keempat. Jakarta: Gramedia.

Putri, S. N. (2018). Analisis Alih Kode Bahasa Guru dalam Kegiatan Pembelajaran di Kelas Bilingual. Kandai 14(1), 119-130 (DOI: 10.24699/jk.v14i1.635) 
Ridwan, H.T.A. (2006). Bahasa dan linguistik. Jakarta: Mestika.

Samsuri. (1986). Analisis bahasa. Surabaya: Jambatan.

Sugiyono \& Sasangka, W. (2011). Sikap masyarakat Indonesia terhadap bahasanya. Yogyakarta: Elmatera Publishing.
Suwito. (1983). Sosiolinguistik: Suatu pengantar awal. Surakarta: Henary Offset.

Yuliadi, A. (2013). Pemertahanan bahasa Bugis di kecamatan Lolak kabupaten Bolaang Mongondow. Kadera Bahasa, 5(1), 33-50 